\title{
Customary Institutions and Rules underlying Conservation Functions of Sacred Sites or Indigenous and Community Conserved Areas
}

\author{
Hasrat Arjjumend*1, Hendrika (Henrie) Beaulieu-Boon ${ }^{2}$ \\ ${ }^{1}$ Université de Montréal Faculté de Droit, Maximilien-Caron Pavilion, C. P. 6128, Downtown, Montreal \\ (Québec) H3C 3J7, Canada. E-mail: hasrat.arjjumend@umontreal.ca \\ ${ }^{1}$ Centre for International Sustainable Development Law, McGill University Faculty of Law, Montreal \\ (Quebec) H3A 1X1, Canada. E-mail: harjjumend@gmail.com \\ ${ }^{2}$ Department of Indigenous Studies, University of Lethbridge, University Hall, 4401 University Drive, \\ Lethbridge (Alberta) T1K 3M4, Canada. E-mail: beaulieu@uleth.ca \\ *Corresponding author
}

How to cite this paper: Arjjumend, H. and Beaulieu-Boon, H.H. (2018). Customary Institutions and Rules underlying Conservation Functions of Sacred Sites or Indigenous and Community Conserved Areas. Grassroots Journal of Natural Resources, 1(2): 1-12. Doi: https://doi.org/10.33002/nr2581.6853.01021

Received: 19 October 2018

Reviewed: 21 November 2018

Provisionally Accepted: 25 November 2018

Revised: 01 December 2018

Finally Accepted: 10 December 2018

Published: 31 December 2018

Copyright $(2018$ by author(s) and

The Grassroots Institute.

This work is licensed under the Creative Commons Attribution International License (CC BY 4.0). http://creativecommons.org/licenses/by/4.0/
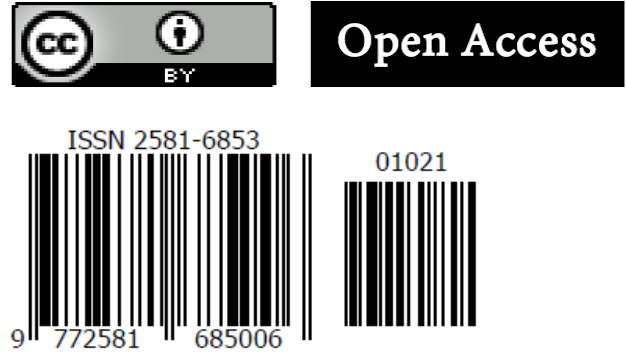

\begin{abstract}
Sacred sites, or indigenous and community conserved areas (ICCAs), are repositories of biological and cultural diversity, the spaces de facto governed by Indigenous peoples or local communities. There are many thousands of these sites across the world, including sacred forests, wetlands, landscapes, village lakes, catchment forests, river and coastal stretches and marine areas. Though the backbone of sacred sites or ICCAs is the robust local governance system of Indigenous/customary institutions and their customary laws/rules, aspects such as institutional analysis, institutional governance, customary laws/rules and management systems are inadequately investigated. This article suggests how customary institutions or rules enable the underlying conservation functions of sacred sites or ICCAs and that due recognition and attention need to be given to indigenous protocols re ICCAs to enable the conservation of biological and cultural diversity. Through enabling legislation or policy, the customary institutions of traditional communities managing the sacred sites can be reinforced and restored. Relevance of sacred sites or ICCAs can be established in biodiversity conservation processes if the resilience of customary institutions and the ability of institutions withstanding external challenges are appreciated.
\end{abstract}

\section{Keywords}

Sacred sites; ICCAs; Indigenous people; Customary institutions; Customary laws 


\section{Introduction}

Indigenous peoples and local communities have for millennia played a critical role in conserving a variety of natural environments and species (Arjjumend et al., 2018). In the $20^{\text {th }}$ century, these areas were popularly known as 'sacred groves' or 'sacred sites;' sites that encompassed all of part of the landscape, waterscape, ecosystem, habitat, woodland, natural site, territory specific species, culturally-significant flora and fauna, and/or religious sites with significant biota that have environmental conservation values and are protected and conserved by Indigenous peoples and/or local communities through religious beliefs, social/cultural/economic motivations and aesthetic values (Arjjumend et al., 2018; Mughal and Kachhawa, 2015; Chaudhry and Murtem, 2015). 'Sacred sites' therefore existed all over the world, including ancient Europe, Japan, China, the Indian subcontinent, South-East Asia, African countries, South and North America, Mexico, Iran and parts of Middle East. Today, the 'sacred sites' may exist either within government-managed protected areas (e.g. national parks, sanctuaries, etc.) or outside formally protected locales. Globally, the UN Conventional on Biological Diversity (CBD) and World Conservation Union (IUCN) have recognized such areas and territories as Indigenous and community conserved areas (ICCAs), which are the spaces de facto governed by Indigenous peoples or local communities with evidently positive outcomes for the conservation of biological and cultural diversity. In 2014, the CBD approved a number of Decisions ${ }^{1}$ that arguably contributed to the normative development of ICCAs (ICCA Consortium, 2014). The ICCA Consortium², a civil society forum, has recently started promoting ICCAs around the world and attempting not only to get policy recognition in various countries, but also to integrate ICCAs with the protected area systems (ICCA Consortium, 2018). The World Conservation Union (IUCN) adopted Motion 29 during the last IUCN World Conservation Congress 2016 in context of ICCAs overlapping protected areas (IUCN, 2016).

The many thousand sacred sites or ICCAs found across the world today include sacred forests, wetlands, landscapes, village lakes, catchment forests, river and coastal stretches and marine areas (Arjjumend et al., 2018). It is estimated that about 420 million hectares of forests (11\% of the world's total) are under community ownership or administration (Molnar et al., 2004), and that this could double in the near future due to increasing policies of decentralization (White et al., 2004). UNEP-WCMC $^{3}$ has established an ICCA Registry (ICCA Registry, 2016), which continuously documents these; including, as Kothari et al. (2012) noted, sacred sites or ICCAs up until 2012 in Australia (50), Bolivia (258), Canada (30), Costa Rica (22), Fiji (150), India (100000-150000), Iran (several hundred), Japan (>1000), Kenya (111), Mexico (301), Namibia (89), Nepal (several hundred), Philippines (156), Russia (475), Senegal (33), China (60000), Madagascar (1016), Tanzania (1457). However, sacred sites/ICCAs may number far more than the current officially designated protected areas (which number about 130000 and are mostly governed by government agencies) and cover as much if not more than the area covered by them (nearly $13 \%$ of the Earth's land surface) (Kothari et al., 2012).

Countless studies have highlighted the role of sacred sites/ICCAs in the conservation of biodiversity across India, including the state of West Bengal (Pandit and Bhakat, 2007), Northeast India (Khumbongmayum et al., 2004) and Eastern Ghats (Gadgil and Vartak, 1976). Two ICCAs,

\footnotetext{
${ }^{1}$ https://www.cbd.int/decision/cop/default.shtml?id=13366; https://www.cbd.int/decision/cop/default.shtml?id=13368; https://www.cbd.int/decision/cop/default.shtml?id=13375; https:/www.cbd.int/decision/cop/default.shtml?id=13382

${ }^{2}$ www.iccaconsortium.org

${ }^{3}$ United Nations Environment Programme (UNEP) - Wold Conservation Monitoring Centre (WCMC)
}

Hasrat Arjjumend, Hendrika (Henrie) Beaulieu-Boon - 
Oorani and Olagapuram, situated on the north-west of Pondicherry (India), found a total of 169 angiosperms (Ramanujam and Kadamban, 2001). Haridasan and Rao (1985) submit that sacred sites or ICCAs are home to a number of plant and animal species, which are not found elsewhere and hence they are very rich in biodiversity. For example, a patch of just $1.4 \mathrm{~km}^{2}$ in Kerala (India) has 722 species of angiosperms; whereas a $90 \mathrm{~km}^{2}$ of Silent Valley National Park (Kerala, India) has 960 species (Haridasan and Rao, 1985). Tiwari, Barik and Tripathi (1998) identified 79 sacred sites and their floristic survey revealed that these sacred sites are home to at least 514 species representing 340 genera and 131 families. They also found that $1.3 \%$ of the total sacred area was undisturbed, $42.1 \%$ had relatively dense forest, $26.3 \%$ had sparse canopy cover, and $30.3 \%$ had open forest. Notably, the species diversity indices were higher for the sacred sites than for the disturbed forest (Tiwari, Barik and Tripathi, 1998). Likewise, in Pallapatty village of Tamil Nadu (India), a total of 133 plant species belonging to 113 genera of 51 families are found in that ICCA and many of them are used for mythical and therapeutic uses. Darlong (1995) observed that they provide safe sites for reproduction of a variety of floral and faunal species. They also help in maintaining the viable populations of pollinators and predators and conserve germplasm (Khiewtam, 1986). Local people are tempted to conservation of such plants owing to their irrefutable lifesaving qualities as well environmental values (Ganesan et al., 2009). The soil itself is especially rich in nutrients and does not experience degradation due to the high biomass and the accumulation of high organic contents in such sites and the decomposition and nutrients released in such ecosystems (Kala, 2011). As a result, the farmers, who have agricultural land in the proximity of such sacred sites or ICCAs, enjoy a relatively higher production of crops in such lands (Kala, 2011). It is apparent that sacred sites generate important ecosystem services for local livelihoods, for example, non-timber forest products (e.g. medicinal plants, fruits, and firewood), firebreaks, watershed protection, and protection of freshwater sources (Lebbie and Guries, 1995, Virtanen, 2002; Ramakrishnan, 1998).

Despite high values and profound ecological impacts of sacred sites, what actually underlies the successful conservation of such sacred sites is still inadequately documented. Basically, the backbone of indigenously conserved sacred sites or ICCAs is the robust local governance system of indigenous/customary institutions and their customary laws/rules. The resilience of customary institutions managing the sacred sites or ICCAs, and the ability of institutions withstanding the threats and challenges from external milieu, are crucial elements that enable conservation of natural resources within sacred sites. Notably, the corresponding Indigenous people and local communities tend to neutralize, cope with, or counterfoil the threatening factors, or to manage the internal dissociating/decaying factors, resulting in the preservation of ecosystems within sacred sites or ICCAs. Therefore, the governance systems of customary institutions sustain the conservation of biological diversity, cultural diversity, ecosystem services and livelihood systems in ICCAs. A plethora of studies undertaken on sacred sites, sacred groves or ICCAs, highlight the religious, social, economic, livelihood, cultural, ethnobotanical, conservation, and development aspects. However, in context of institutional analysis, institutional governance, customary laws/rules and management systems, there is paucity of available literature. Therefore, the present article encompasses these less-explored dimensions of the sacred sites or ICCAs, and suggests how customary institutions or rules enable the underlying conservation functions of these landscapes. Insights explored in this article will assist in facilitating models of community-driven conservation of nature, culture and human values. 


\section{Communities' Belief Systems: A driving force behind conservation}

The traditional basis of conservation is older than the modern conservation movement (BorgerhoffMulder and Coppolillo, 2005). Man's reverential relationship with plants and animals has not vanished with the burgeoning progress of science and technology (Sivakumar et al., 2014). Sacred sites are the best representative sites of the mosaic of human-nature interaction based on cultural, spiritual, religious and socio-economic foundations (Arjjumend et al., 2018).

The belief systems of communities have been widely documented as powerful forces driving conservation of sacred sites. Scholars have witnessed that traditional beliefs play key roles in the conservation of local biodiversity regardless of its use value (Berkes et al., 2000; Robson, James and Berkes, 2010; Turner, Ignace and Ignace, 2000; Shastri et al., 2002). They reiterate that traditional conservation ethics are capable of protecting various species in particular and the environment in general as long as the local communities continue their stakes in it. Traditional belief systems are infused with practices and concepts, and modes of teaching and learning that are embedded within resource stewardship and conservation (Rim-Rukeh, Irerhievwie and Agbozu, 2013). Traditional communities adhering to traditional belief systems, often consider natural objects as bearing supernatural powers; rocks, streams, ponds, lakes, trees, land may all be perceived as animated. The belief system holds that these specifically located spirits of object/place protect community members from harm, famine, bareness, impotence, drought, epidemics and war. While in some societies animated objects or landscape are understood as containing the power of specific Gods, it is more common for societies to understand animated landscapes and objects as components of animated Nature. In both cases however, whether Gods or Nature, any violation of omission or erroneous commission (for example, violation of taboos) results in anger or retribution on the part of the Gods or Nature. Hence, a cultural system holds to a very high esteem all the precepts of the laws of the Gods or Nature (Shastri et al., 2002). The taboos and beliefs also have legal backing in the rules and institutions of the communities which are strong enough to make people obey the religious and cultural regulations (Cox, 2000). Social taboos invariably exist in all cultures throughout the world, and represent a class of informal institutions, where traditional, religiously governed norms or taboo system define human behaviour. These taboos remain the prime factor guiding their conduct towards the utilization of natural resources (Rim-Rukeh, Irerhievwie and Agbozu, 2013). Similar cases are documented in Kenya where the elders of Kaya Kinondo forest have an innermost sanctum where community elders are buried, and only married men may make sacrifices to ancestors (Bagine, 1998). These traditional rules have conserved these forests for many years and preserved them as home to rare plant species. More than half of Kenya's rare plants occur on the coast, most of which are within Kayas (Nyamweru, 1996).

We see therefore, that in many parts of the world, local habitat taboos provide effective protection of smaller ecosystems, for example, in West Africa (Lebbie and Guries, 1995; Kokou et al., 1999), East Africa (McClanahan et al., 1997; Mgumia and Oba, 2003), Southern Africa (Byers et al., 2001), India (Gadgil and Guha,1993) and China (Liu et al., 2002). South Asian nations closely integrated philosophies of religion and Nature. Ever since the 'Vedic' era, there was a strong notion that man should not destroy members of his ecology or destroy any aspect of nature (Sivakumar $e t$ al., 2014). Notably, some traditions or taboos are against the women. For instance, menstruating women were not allowed to enter premises of sacred sites (McLeod, 1981). Most often the rules and regulations are enshrined in religious or cultural beliefs of traditional communities, and are enforced by prohibitions. These may or may not have legal backing, but the beliefs have been strong enough to make people obey the regulations (Rim-Rukeh, Irerhievwie and Agbozu, 2013). 


\section{Customary Institutions and Governance}

Significant cases have been reported that prove the existence and effectiveness of customary institutions managing the sacred sites/ICCAs in various parts of world. For instance, sacred sites of Meghalaya (India), the village forest lands set aside for religious purposes under the traditional land tenure system (Gurdon, 1975), remain well utilized under traditional parameters. It is an offense, customarily, to cut trees from sacred sites except for cremation and religious purposes. Such norms are commonly practiced by the communities managing sacred sites. So, it is pertinent to understand the anatomy of institutions and governance systems that enable conservation functions of ICCAs.

Uphoff (1986) explained the institutions that can be understood as "complexes of norms and behaviours that persist over time by serving some socially valued purposes". Chambliss (1999) highlighted that the institutions provide shared understanding of the cultural meaning of activities. Narayan et al. (2000) define the institutions as follows: "institutions often have both formal and informal dimensions, with some part of their operation governed by explicit rules, rules and procedures (that) also shape behaviours. Institutions affect people's opportunities by establishing and maintaining their access to social, material and natural resources. They reinforce capacities for collective action and self-help, while their absence can contribute to immobilization and inertia".

A particular community's endogenous institutions are inevitable components of any conservation movement. Thus, any conservation or development initiative requires viable community institutions characterized by a democratic governance system, adequate representation of various communities, legitimacy, internal resilience, robust customary laws/rules, transparent decisionmaking processes, and equitable sharing of benefits (Arjjumend, 2001; Perelman, 1984). A similar observation is made by Margules and Pressey (2000) who stated that the effective systems for the conservation of biological diversity must be representative and persistent. As Mandondo (1997) puts it, the parts of nature are protected under traditional norms according to two different premises: the controls can be either space or species-based. In sacred sites/ICCAs, some species-based controls are linked to beliefs about spirits, deities, taboos and their dwelling places. Virtanen (2002) argues that some species are protected for their utilitarian value, such as medicinal plants, fruits trees, and ecosystem service. He suggests that conservation is pursued at the ecosystem level due to interests in space-based controls over larger areas under tree cover, such as sacred forest (Virtanen, 2002). Due to their embeddedness in specific cultural systems the sacred sites have also a spiritual dimension, and their persistence cannot be assessed separately from the cultural institutions which make them meaningful and valuable for the local population (Perelman, 1984).

Community-governed endogenous institutions are generally flexible, responsive to variety of factors, and adaptive to internal changes (Arjjumend, 2005). Notably, these institutions are often self-motivated and self-financed, as governance of ICCA is crucial for people whose livelihoods and cultural identity are intricately imbedded with the natural resources (Borrini-Feyerabend and Hill, 2015; Smyth, 2015). The customary institutions are peculiar to their cultures. What is most common is that such institutions represent local rights-holders - people first in line to pay the price for management decisions and who possess traditional knowledge, skills and the accumulated local experience necessary to protect or restore specific sites and/or use natural resources in sustainable ways (Kothari, 2006). However, in modern contexts such institutions also have limitations. For instance, some institutions do not concur with the principles of universal human rights and participation in decision-making or accountability. Additionally, other institutions often encounter 
problems in their relationship with governments - in particular, at the interface between traditional and modern institutions (Borrini-Feyerabend and Hill, 2015). Yet, the customary (organic) institutions of traditional communities represent superior traits vis-à-vis State-promoted modern institutions (Arjjumend, 2005).

Attributes of governance functions inside a customary institution are of paramount importance from conservation angles. Dudley $(2008$, p.9) defines governance for nature conservation as: "a clearly defined geographical space, recognised, dedicated and managed, through legal or other effective means, to achieve the long-term conservation of nature with associated ecosystem services and cultural values". Borrini-Feyerabend and Hill (2015) further refine governance as: "governance is not only about who holds authority de jure, but also about who makes decisions de facto, and about how these decisions are made". A governance framework has also been conceptualized by IUCN in the context of conservation of formally protected areas, but it applies to informal community-driven conservation of landscapes or waterscapes, especially sacred sites or ICCAs (Borrini-Feyerabend et al., 2013). Also important is the quality of governance in place, which needs to be measured on certain critical parameters such as legitimacy and voice, direction, performance, accountability, fairness and rights.

Arjjumend (2001) undertook a study in India on community institutions from the perspectives of governance, participation, legitimacy, effectiveness and functional outcomes. He noted that a community's traditional institutions exhibit the characteristics of a good governance system. In particular, decision making and benefit sharing were recorded as fully participatory. This good governance model has facilitated the maintenance of institutions over time due to their immense internal strengths. In his particular study, Arjjumend $(2001 ; 2005)$ also found that the fact that the community's traditional institutions had religious or specific social class foundations, required a high degree of people's participation, that too, a purely functional one. An important factor behind the success of people's participation is the evolution of such institutions from traditional, cultural and livelihood needs, values and ethos of the concerned community. Arjjumend (2001) further maintained that the Indigenous knowledge of Indigenous people and local communities and their inherent abilities to evolve efficient management systems all made conservation sustainable and locally controlled. In that ancient paradigm of conservation, the "traditions" or "social mechanisms" survived because of its close fit to the needs, values and interests of that society, while knitting together the social bonds for common interest and mutual advancement.

\section{Customary Rules and Laws}

In India, particular patches of forests are designated as sacred sites under customary law and are protected from any product extraction by the community. These aspects interplay with the governance functions of customary institutions. According to Borrini-Feyerabend and Hill (2015), customary and local institutions and rules are as diverse and complex as the cultures of Indigenous peoples and local communities (also see, Kala, 2011). Land may be collectively owned and managed, but particular resources, such as a type of tree, may be owned or managed individually or on a clan basis, for which specific procedures and/or rituals may need to be respected (BorriniFeyerabend and Hill, 2015).

The necessity of natural resources for human survival spurred traditional communities to evolve systems underpinned by customary laws and practices, which in long run resulted in the conservation of the surrounding natural resources (Kala, 2011). It is evident that various human 
philosophies and belief systems have contributed significantly to the conservation of forests, biodiversity and landscapes, and that these ideologies were concretized in customary norms, practices and systems. Established customary rules vary from place to place and site to site since they respond to environmental possibilities, but often include prohibitions on the felling of trees and the killing of animals, except when trees are required for the construction and repair of religious buildings or in special cases (Brandis, 1897; Ramakrishnan, 1998; Bassi, 2017; Jayalaxshmi and Berardi, 2016). Because of these restrictions, the biodiversity in such sacred sites are preserved over many generations, and still exist today. For instance, in a study of Pachmarhi Biosphere Reserve (India), Kala (2011) has documented that the 'padihar' (saman) has been given the responsibility to take care of and worship the village deity in the sacred area. Usually, the head of the village or Padihar collected the fruits from the sacred site, particularly Madhuca indica and Tamarindus indica.

In the words of Srivastava (2004), in order to understand customary law, one needs to look at what custom itself is in the first place. Custom is not a term that can be constrained to one definition, though in common parlance it can be understood as uniformity of conduct of people under similar circumstances. It is a practice that by its common adoption and long unvarying habit has come to have a force of law (Garner, 2004). A custom is a usage by virtue of which a class of persons belonging to a defined section in a locality is entitled to exercise specific rights against certain other persons or property in the same locality. ${ }^{4}$ Custom, if the law is to uphold it as right, should be immemorial in origin, certain, reasonable in nature and continuous in use. Both national and international courts play an important role in the application of custom (Krishnan, 2000). The court will attest the 'jural quality' of the custom. When a customary right is upheld by the court it becomes customary law. But to obtain that legal status, the custom must be ancient, certain and reasonable and, in derogation of the general rules of law, be construed strictly (Krishnan, 2000). Unlike State laws, customary laws emerge from within the community and command social acceptance and observance. Statutory law is uniform whereas customary law is an adaptive, flexible, evolving body of norms and rules governing the behaviour of communities. While the former is for the community, the latter is rooted in the community (Upadhyaya, 2003). Selfimposed limitations on forest clearance, restriction on hunting, taboos on hunting or harvesting certain species, protection of sacred groves for religious reasons, rotational use of catchment areas (hunting and fishing reserves), lineal ownership of nature zones and use of appropriate local technologies which lower the impact of use or even increase biodiversity, are some examples of cultural controls or customary laws in case of sacred sites or ICCAs.

Srivastava (2004) rightly articulates that the biggest advantage of a customary law is that it comes from the community and is therefore, simple and easy to understand and follow. Moreover, it is friendlier to the locality or community from where it has emerged. It is well known that sacred sites, in particular, are managed and governed by customary laws evolved within a community institution. These customary institutions also act in the form of custodial associations inculcating the 'custodian responsibility' and 'custodian right' with endowments of nature. By virtue of the customary laws, the community institutions managing the sacred sites or ICCAs are deeply rooted in the ethical philosophy of respective Indigenous people and local communities.

${ }^{4}$ State of Bihar v. Subodh Gopal Bose (A.I.R. 1968 SC 281) 


\section{Conclusion}

Recognition and promotion of customary institutions of Indigenous people or local communities has utmost value and demands the urgent attention of stakeholders of biodiversity conservation. Contrary to such earnestness, State agencies seldom recognize customary institutions and rules of traditional communities and impose externally crafted modern hierarchical institutions on them in their hurry to achieve conservation objectives. In the particular context of ICCAs, or even formally protected areas for that matter, if local institutions are promoted as a tool to preserve biodiversity yet separated from the institutions that ensure their organic evolutionary process, they tend to soon lose their legitimacy. According to Virtanen (2002), sacredness is a powerful means of conservation only when it is linked to belief systems and normative controls for enforcement. Hence, both the State and external societies need to change their attitudes towards traditional communities and their sacred sites, especially as this pertains to indigenous peoples, and the sacred sites or ICCAs. This re-attention alone will reverse the degradation process of natural ecosystems, not only in ICCAs but also in formally protected areas. For example, sacred sites can often withstand the influx of outsiders with different belief systems, or penetration of new social doctrines, only if the endogenous local institutions are given appropriate legal authority to continue enforcing local norms (Virtanen, 2002). On the part of States, it is essential not to place newly created local institutions above customary organic institutions for administrative convenience. Creation of enabling legislation and offering due recognition to customary institutions managing the sacred sites needs to be emphasized. Another significant dimension of recognition is respecting the 'collectiveness' spirits of traditional communities. This collectiveness is the manifestation of cultural and group identity that overrides the perceptions of a sacred site as property in the western sense. Indeed, the collectiveness or sense of collective rights harbors a strong basis for the organic shaping and functioning of customary institutions. If the customary institutions and laws of Indigenous peoples and local communities managing sacred sites or ICCAs are recognized and appreciated, the customary collective rights of traditional communities will automatically be recognized. It will further strengthen and reinforce the conservation of natural treasures both inside formally protected areas and in ICCAs.

To establish the relevance of sacred sites or ICCAs in larger objectives of conservation inside or outside formal protected areas, the resilience of community institutions managing the natural resources, biodiversity, cultural affairs, etc. in the sacred sites or ICCAs, and the ability of institutions withstanding the threats and challenges from external milieu need to be appreciated to enable conservation of natural resources within sacred sites. The process of recognition of ICCAs also includes an emphasis on studying the unexplored dimensions of sacred sites. No doubt, plenty of literature exists concerning sacred sites, sacred groves or ICCAs highlighting the religious, social, economic, livelihood, cultural, ethnobotanical, conservation, and development aspects. However, in the context of institutional analysis, institutional governance, customary laws/rules and management systems, there is paucity of studies. Therefore, future studies are called for to address the representation of different strata of local communities, underlying motivational factors, governance functions, people's participation in various affairs, sustainability, legitimacy, empowerment, equity, conservation-related impacts, customary laws/rules, custodian rights of the community institutions managing the sacred sites or ICCAs, rules/laws for internal management of institution, laws/rules of delivering conservation functions, laws/rules regulating the accrual of benefits and its sharing, rules/regulation of resolving conflicts and executing the penal system, interaction or interface with statutory legal system, impact of customary laws on the conservation status, and implications in dominating national conservation laws. Such a framework of future 
studies encompassing sacred sites or ICCAs would enhance its legitimacy in the official or formal conservation of biodiversity and landscapes or waterscapes.

\section{References}

Arjjumend, H. (2001). Anatomy of Village Institutions and Their Interrelationships, Bhopal: Samarthan - Centre for Development Support, pp.116.

Arjjumend, H. (2005). "Governance and Participation in Community Initiated Associations and Sustainable Development in Bundelkhand, Madhya Pradesh”, Eastern Anthropologist, 3(4):451-464.

Arjjumend, H., Koutouki, K., Fagan, G.H. and Shibata. S. (2018). "International Overview of Sacred Sites and Indigenous and Community Conserved Areas (ICCAs) and the Need for Their Recognition", Global Environmental Studies, vol. 10, March 2018.

Bagine, R. (1998). "Biodiversity in Ramogi Hill, Kenya, and its evolutionary significance", African Journal of Ecology, 36 (3):251-263.

Bassi, L. (2017). "Measuring biodiversity in ICCAs: problems and possibilities", Practicing the Commons: Self-Governance, Cooperation, and Institutional Change, XVI Biennial Conference International Association for the Study of the Commons, Utrecht, 10-14 July 2017. Online: https://www.iasc2017.org/wp-content/uploads/2017/06/3C_Leonardo-Bassi.pdf

Berkes, F. (2008). Sacred Ecology (2nd edition), New York and London: Routledge.

Borgerhoff-Mulder, M. and Coppolillo, P. (2005). Conservation: Linking Ecology, Economics, and Culture, Princeton, New Jersey: Princeton University Press.

Borrini-Feyerabend, G. and Hill, R. (2015). "Governance for the conservation of nature", in G.L. Worboys, M. Lockwood, A. Kothari, S. Feary \& I. Pulsford (eds.), Protected Area Governance and Management, pp. 169-206, Canberra: ANU Press.

Borrini-Feyerabend, G., Dudley, N., Jaeger, T., Lassen, B., Broome, N.P., Phillips, A. and Sandwith, T. (2013). Governance of Protected Areas: From understanding to action, Gland: IUCN.

Brandis, D. (1897). Indigenous Indian Forestry: Sacred Groves, Oriental Institute, England.

Byers, B.A., Cunliffe, R.N. and Hudak, A.T. (2001). "Linking the conservation of culture and nature: A case study of sacred forests in Zimbabwe", Human Ecology, 29:187-218.

Chambliss, W.J. (1999). Power, Politics and Crime, Boulder, Colombia: Westview Press.

Chaudhry, P. and Murtem, G. (2015). "Role of sacred groves, value education and spirituality in conserving biodiversity with special reference to Arunachal Pradesh state of India", Int. J. Society Systems Science, 7(2): 151-180.

Cox, P.A. (2000). "Will tribal knowledge survive the millennium?”, Science, 287:44-45.

Darlong, V.T. (1995). "Wildlife preservation and community action", in B.K. Tiwari \& S. Singh (eds.), Ecorestoration of Degraded Hills, Shillong: Kaushal Publications.

Dudley, N. (2008). Guidelines for Applying Protected Area Management Categories, Gland: IUCN.

Gadgil, M. and Vartak, V.D. (1976). "Sacred Groves of Western Ghats in India," Economic Botany, 30: $152-160$.

Gadgil, M. and Guha, R. (1993). This fissured land: an ecological history of India, Delhi: Oxford University Press.

Ganesan, S., Ponnuchamy, M., Kesavan, L. and Selvaraj, A. (2009). "Floristic composition and practices on the selected sacred groves of Pallapatty village (reserved forest), Tamil Nadu", Indian Journal of Traditional Knowledge, 8(2):154-162. 
Garner, B.A. (ed.) (2004). Black's Law Dictionary, Eighth Edition, Minnesota (USA): West Publishing Company.

Gurdon, P.R. (1975). The Nature Races of India: The Khasis, New Delhi: Cosme Publication.

Haridasan, K. and Rao, R.R. (1985). Forest Flora of Meghalaya, vol.1, Dehradun: Bishen Singh.

ICCA Consortium (2014). "ICCAs in Decisions of CBD COP12, Pyeongchang, 2014. Online: https://www.iccaconsortium.org/index.php/2014/12/14/decisions-of-cbd-cop-12pyeongchang-2014/

ICCA Consortium (2018). "XIIth (Extraordinary) General Assembly of the ICCA Consortium, 30 June 2018, Montreal, Canada", Online: https://www.iccaconsortium.org/wpcontent/uploads/2018/05/Minutes-EGA-17.08.2018-FINAL.pdf

ICCA Registry (2016). Accessed on 4 April 2016, URL: http://www.iccaregistry.org/en/about

IUCN (2016). IUCN Resolutions, Recommendations and Other Decisions. Gland, Switzerland: IUCN.

Jayalaxshmi, M. and Berardi, A. (2016). "Bridging Indigenous and Scientific Knowledge. Local Ecological Knowledge Must Be Placed at the Center of Environmental Governance." Science 352: 1274-75. Doi: 10.1126/science.aaf1160.

Kala, C.P. (2011). "Traditional Ecological Knowledge, Sacred Groves and Conservation of Biodiversity in the Pachmarhi Biosphere Reserve of India", Journal of Environmental Protection, 2: 967-973

Khiewtam, R.S. (1986). "Ecosystem Function of Protected Forests of Cherrapunji and Adjoining Areas", PhD Thesis, North-Eastern Hill University, Shillong.

Khumbongmayum, A.D., Khan, M.L. and Tripathi, R.S. (2004). "Sacred Groves of ManipurIdeal Centres of Biodiversity Conservation," Current Science, 87: 430-433.

Kokou, K., Caballe, G., Akpagana, K. and Batawila, K. (1999). "Forest islands of southern Togo: dynamics and relationship with surrounding vegetations", Revue D Ecologie-La Terre Et La Vie, 54: 301-314.

Kothari, A. (2006). "Community conserved areas: towards ecological and livelihood security", PARKS, 16(1): 3-13.

Kothari, A. (2006). "Community conserved areas: towards ecological and livelihood security", PARKS, 16(1).

Kothari, A., Corrigan, C., Jonas, H., Neumann, A. and Shrumm, H. (eds.) (2012). "Recognising and Supporting Territories and Areas Conserved by Indigenous Peoples and Local Communities: Global Overview and National Case Studies", Secretariat of the Convention on Biological Diversity, ICCA Consortium, Kalpavriksh, and Natural Justice, Montreal, Canada, Technical Series no. 64, 160 pp.

Krishnan, B.J. (2000). "Customary Law", Seminar, 492. Accessible at URL: http://www.indiaseminar.com/2000/492/492\%20b.\%20j.\%20krishnan.htm

Lebbie, A.R. and Guries, R.P. (1995). "Ethnobotanical Value and Conservation of Sacred Groves of the Kpaa-Mende in Sierra-Leone", Economic Botany, 49: 297-308.

Liu, H.M., Xu, Z.F., Xu, Y.K. and Wang, J.X. (2002). "Practice of conserving plant diversity through traditional beliefs: a case study in Xishuangbanna, southwest China", Biodiversity and Conservation, 11:705-713.

Mandondo, A. (1997). "Trees and spaces as emotion and norm laden components of local ecosystems in Nyamaropa communal land, Nyanga District, Zimbabwe", Agriculture and Human Values, 14:353-372.

Margules, C.R. and Pressey, R.L. (2000). "Systematic conservation planning", Nature, 405:243253. 
McClanahan, T.R., Glaesel, H., Rubens, J. and Kiambo, R. (1997). "The effects of traditional fisheries management on fisheries yields and the coral-reef ecosystems of southern Kenya", Environmental Conservation, 24:105-120.

McLeod, M.D. (1981). The Ashanti. British Museum Publication Ltd.

Mgumia, F. and Oba, G. (2003). "Potential role of sacred groves in biodiversity conservation in Tanzania", Environmental Conservation, 30:259-265.

Molnar, A., Scherr, S. and Khare, A. (2004). "Who conserves the world's forests: community driven strategies to protect forests and respect rights", Forest Trends and Ecoagriculture Partners, Washington D.C.

Mughal, R. and Kachhawa, G.M. (2015). "A Study of Sacred Groves Existing in Different Religious Patches of Poonch District", Periodic Research, 1(1): 1-7.

Narayan, D., Patel, R., Schafft, K., Rademacher, A. and Koch-Schulte, S. (2000). Voices of the Poor: Can anyone hear us? Voices from 47 Countries, Washington, DC: The World Bank.

Nyamweru, C. (1996). "Sacred Groves Threatened by Development. The Kaya Forests of Kenya", Cultural Survival Quarterly, 19-21.

Pandit, P.K. and Bhakat, R.K. (2007). "Conserving of Biodiversity and Ethnic Culture through Sacred Groves in Midnapore District, West Bengal, India," Indian Forester, 133(3): 323344.

Perelman, C. (1984). Le raisonnable e le deraisonnable en droit: au-dela du positivism juridique, Paris: Librairie Generale de Droit et de Jurisprudence.

Ramakrishnan, P.S. (1998). "Conserving the Sacred for Biodiversity: The Conceptual Framework," in P.S. Ramakrishnan, K.G. Saxena \& U.M. Chandrashekara (eds.), 'Conserving the Sacred for Biodiversity Management', Boca Raton (USA): Science Publishers.

Ramanujam, M.P. and Kadamban, D. (2001). "Plant biodiversity of two tropical dry evergreen forests in the Pondicherry region of South India and the role of belief systems in their conservation", Biodiversity Conservation, 10:1203-1217.

Rim-Rukeh, A., Irerhievwie, G. and Agbozu, I.E. (2013). "Traditional beliefs and conservation of natural resources: Evidences from selected communities in Delta State, Nigeria", International Journal of Biodiversity and Conservation, 5(7):426-432. DOI: 10.5897/IJBC2013.0576

Robson, J.P. and Berkes, F. (2010). "Sacred Nature and Community Conserved Areas", in Sarah Pilgrim \& Jules N. Pretty (eds.), Nature and Culture: Rebuilding Lost Connections, London/Washington: Earthscan.

Shastri, C.M., Bhat, D.M., Nagaraja, B.C., Murali, K.S. and Ravindranath, N.H. (2002). "Tree species diversity in a village ecosystem in Uttara Kannada district in Western Ghats, Karnataka", Current Science, 82:1080-1084.

Sivakumar, K.P., Akhila, S.N. and Jaya, D.S. (2014). "Indigenous Reverence for Environment: A Review on Sacred Groves in India", International Conference on Indigenous Initiatives for Environment and Development, 28-29 June 2014, Micro Business College, Ambo, Ethiopia.

Smyth, D. (2015). "Indigenous Protected Areas and ICCAs: Commonalities, Contrasts and Confusions", PARKS, 21(2): 73-84.

Srivastava, N. (2004). "Customary Law and the Protection of Indigenous Knowledge in India", Briefing Paper 2, November 2004, New Delhi: Gene Campaign.

Tiwari, B.K., Barik, S.K. and Tripathi, R.S. (1998). "Sacred Groves of Meghalaya", in Ramakrishnan, P.S., K.G. Saxena \& U.M. Chandrashekara, 1998 (eds.), Conserving the Sacred for Biodiversity Management, Boca Raton (USA): Science Publishers. 
Turner, N.J., Ignace, M.B. and Ignace, R. (2000). "Traditional Ecological Knowledge and Wisdom of Aboriginal Peoples in British Columbia", Ecol. Appl., 10(5):1275-1287.

Upadhyaya, V. (2003). “Customary Rights over Tank: Some Plain Talking on Limits of Customs", Economic and Political Weekly, November 1, 2003.

Uphoff, Norman (1986). Local Institutional Development: An Analytical Sourcebook with Cases, Boulder, Colorado: Kumarian Press.

Virtanen, P. (2002). "The Role of Customary Institutions in the Conservation of Biodiversity: Sacred Forests in Mozambique", Environmental Values, 11(2):227-141.

White, A., Khare, A. and Molnar, A. (2004). "Who Owns, Who Conserves, and Why it Matters", Forest Trends, Washington. 